\title{
Efficacy of the Bar Model Method of Teaching Mathematics to Year 7 Students: Case Study of Teachers in Brunei Darussalam
}

\author{
Ernie Sofinah Matzin \\ Duli Pengiran Muda Al-Muhtadee Billah College \\ Gadong BE 1318, Bandar Seri Begawan, Brunei Darussalam \\ E-mail: erni.matzin@smmd.moe.edu.bn \\ Lawrence Mundia (Corresponding author) \\ Sultan Hassanal Bolkiah Institute of Education, Universiti Brunei Darussalam \\ Jalan Tungku Link, Gadong BE 1410, Bandar Seri Begawan, Brunei Darussalam \\ E-mail: lawrence.mundia@ubd.edu.bn
}

Received: May 30, 2020 Accepted: June 21, 2020 Published: June 30, 2020

doi:10.5296/jei.v6i1.17154ＵRL: https://doi.org/10.5296/jei.v6il.17154

\begin{abstract}
Mathematics is a subject that challenges many Brunei secondary school students. The Bar Method of instruction uses visual or pictorial representations to make mathematics easier to understand. The survey participants consisted of 127 randomly selected teachers (24 males and 103 females). Male teachers had significantly higher negative attitudes toward the BMM strategy than their female counterparts. The predictor variables that were significantly related to effective teaching of mathematics using the BMM included gender, age, Experience in using the BMM, Positive opinions on BMM, and district of residence. Evidence from the present study showed that the BMM was not much used by many school teachers. Only a small number or percentage of teachers used the BMM strategy when instructing students in mathematics most likely due to lack of skills and experience in using the method. However, both genders expressed the desire to use the BMM strategy in future, an indication of the degree to which the BMM is rapidly gaining popularity. Further large scale mixed-methods research employing interview probes was recommended to gain additional insights.
\end{abstract}


Keywords: Mathematics education, Teaching mathematics, Teacher education, Bar Model Method, Brunei

\section{Introduction}

Mathematics is a subject that challenges many students in Brunei particularly males (Metussin, 2015). The Bar Model Method (BMM) of teaching and learning mathematics makes use of bar diagrams to concretely model facts given in a word problem (Walker, 2005). Walker (2005) further stressed that the use of this strategy has proven to be a very successful method for students in organizing information. According to Yeap (2011), the BMM is used as a tool to help students solve arithmetic and algebraic word problems. The strategy is useful to students as it helps them to visualize the mathematical problem by drawing pictorial representations of the data to be analyzed (J. N. C. Huat \& L. K. Huat, 2001; Veloo \& Lopez, 1994). In Singapore, this method is taught to primary school children who need concrete materials and approaches to solve arithmetic and algebraic word problems (Kho, 1987; Ng \& Lee, 2009). Once students understood the structure of the mathematical problem, they were more likely to be able to solve it (Kho, 1987, 2009).

\subsection{Theoretical Framework of the Study}

The theoretical framework for this study is guided by the constructivist theory of learning. The constructivist theory is based on the principle of encouraging students to construct, develop and challenge new knowledge by actively taking part in the teaching and learning process through social interaction (Glasersfeld, 1989). For students to be able to do this, they have to participate in a series of activities designed by a knowledgeable adult which aim to provide the student with varying learning opportunities. The constructivist theory stresses the importance of teaching toward supporting student ability. The Bar Model Method (BMM) strategy is mainly an action that develops and supports the constructivist theory's problem representation phase.

\subsection{Mathematics Problem Solving}

Problem solving serves as a major focus in the teaching and learning of mathematics and is a fundamental task when it relates to mathematics, and therefore it is considered central to any mathematics instruction. Principles and Standards for School Mathematics suggested that students should master problem-solving skills, particularly mathematical word problems (National Council for Teachers of Mathematics-NCTM, 2000). The ability to problem-solve and think critically is highly regarded as an essential $21^{\text {st }}$ Century knowledge economy skill (Hargreaves, 2003). In order to master mathematical word problem-solving, they need the support for problem solving strategies that can oversee the understanding and manipulation of information through visual representation.

Cawley, Fitzmaurice-Hayes, and Shaw (1988) defined mathematical problem-solving as "the interpretation of information and the analyses of data to arrive at a single acceptable response or to provide the bases for one or more arguable alternatives" (p. 167). According to them, there are three types of problems in the mathematical problem-solving area, namely; word problems, subject area (e.g., science and recreation) application problems, and 
decision-making and argument problems (Cawley et al., 1988). Among these types of problems, the word problems extending from simple to complex are the most common in the mathematical problem-solving area of both elementary and secondary school mathematics curricula (Cassel \& Reid, 1996; Cawley et al., 1988; Jonassen, 2003).

Mathematical problem-solving has been given considerable attention in typical mathematics curriculum and instruction (Miller \& Mercer, 1993; Moore \& Carnine, 1989). Recommendations for higher order mathematical skills such as problem-solving, has been the focus of national mathematics instruction and curriculum (Jitendra \& Xin, 1997; Miller \& Mercer, 1993). In effect, a strong emphasis on mathematical problem-solving as an essential mean for students to construct their own understanding of mathematical ideas and processes and to develop their logical thinking (Taplin, 2006). Furthermore, several researchers have argued that mathematical problem-solving is imperative for students to apply their acquired mathematical knowledge and skills when dealing with unanticipated problem-solving situations in their everyday life (Bottge \& Hasselbring, 1993; Taplin, 2006; van de Walle et al., 2004). Consequently, the National Council for Teachers of Mathematics (NCTM, 2000) has highlighted that problem-solving should be the first precedence of the curriculum at all grade levels, and students were encouraged to explore and solve many mathematical problems in meaningful real-life contexts (NCTM, 1989, 2000).

\subsection{Theoretical Models of Mathematical Word Problem-Solving}

Solving mathematical word problems has been identified as a complex process involving a variety of tasks that require students to possess certain skills (Cawley \& Miller, 1986). To understand the processing components of word problem-solving and to identify specific skills which contribute to students' mathematical word problem-solving performance, much attention has been paid to theoretical models of mathematical word problem-solving. The theoretical models of mathematical word problem-solving are grounded in the information-processing theory from cognitive sciences. Several cognitive scientists have proposed information-processing models of problem-solving (Newell \& Simon, 1972; Shaw, 1981). As an example, Wallas (1926) introduced a series of four-step processes in problem-solving. These four steps are (a) preparation, (b) incubation, (c) illumination, and (d) verification. At the preparation stage, the solver gathers information about the problem. At the incubation stage, the solver puts aside the problem to do other activities. At the illumination stage, the solver finds the key to the solution. At the verification stage, the solver checks the solution.

Similar to Wallas's four steps of problem-solving, Polya (1957) conceptualised problem-solving as a four-stage process which consist of: (a) understanding the problem, (b) devising a plan, (c) carrying out the plan, and (d) looking back. In the first stage (understanding the problem stage), the solver restates the problem, identifies the goal, and draws a picture or diagram to understand the problem. At the second stage (devising a plan stage), the solver plans a potential solution and paraphrases the problem. At the third stage (carrying out the plan stage), the solver refines and transforms the problem into a solution, checks each step, and defines each step with relation to the problem. At the last stage (looking 
back stage), the solver checks the previous steps to verify that the answer is reasonable and correct. In this stage, the solver finally confirms results and arguments in addition to assessing the effectiveness, accuracy, and usefulness of a solution for solving other problems. Newell and Simon (1972) analysed problem-solving as a two-step process namely, (a) understanding process and (b) search process. The understanding process requires the solver to understand the problem itself and to identify the initial information to solve the problem. The solver uses a variety of perceptual stimuli, such as drawing a diagram or picture, in this process. On the other hand, the search process requires the solver to find or calculate the solution to the problem.

Based on these information-processing models of problem-solving, several researchers have proposed theoretical models of mathematical word problem-solving. As an example, after identifying the five essential knowledge components for mathematical word problem-solving namely, linguistic, semantic, schematic, strategic, and procedural knowledge components, Mayer (1992) theorized mathematical word problem-solving as a two-way process consisting of: (a) problem representation and (b) problem solution. The problem representation process involves paraphrasing and/or visualizing thorough illustrations such as drawing a diagram or picture, and hypothesizing a problem. This process also involves transforming linguistic and numerical information of the problem into mathematical equations and operations. Consequently, the problem solution process involves the planning and executing of the strategies to find a solution to the problem. On the other hand, Cawley et al., (1988) proposed three stages in mathematical word problem-solving process which includes: (a) confrontation, (b) exercise, and (c) examples. In the confrontation stage, the solver recognizes and understands a problem without a final solution. At the exercise stage, the solver constructs a representation of the problem by connecting it to his/her prior experience. In the final stage, example stage, the solver selects the appropriate strategies and finally solves the problem.

Extending from the previous word problem-solving models, which only focus on the cognitive processing components of word problem-solving, Montague (1992) developed a comprehensive model that consists of cognitive and meta-cognitive processes of mathematical word problem-solving. In this model, the cognitive process encompasses the problem representation and problem solution process identified by Mayer (1992). The meta-cognitive process involves self-awareness of cognitive knowledge, using cognitive processes, and regulating and monitoring cognitive performance.

Integrating the word problem-solving processes into schema theory, Jitendra and Hoff (1996) presented a three-stage schema-based processing model in mathematical word problem-solving. The first stage involves processing problem schemata. The solver identifies definite characteristics, features, and facts of the situation of a problem. At the next stage, the solver activates action schemata by selecting strategies and a mathematical operation for the problem. At the last stage, the solver executes the mathematical operation and reaches a solution for the problem by using strategic knowledge. 


\subsection{Problem-Solving Skills among Secondary School Students in Brunei}

The underachievement of students in mathematics has been a subject of debate over the years, and it has not only been a cause of concern among parents but also the teachers as well as other stakeholders of the country. Taking such a development into consideration, scholars in mathematics education have carried out numerous studies to investigate and identify the causes of the problem along with hoping to identify potential solutions for the underachievement among students. Many students in Brunei still have difficulties in solving word problems in mathematics (Sainah, 1998; Saman, 2000; Raimah, 2001; Radiah, 2001). It is thus the goal of the present study to examine how the Bar Model Method strategy may help students in the context of Brunei to be more efficient and competent in solving word problems.

Problem-solving has always been a challenging aspect in relation to mathematics subject at school levels, while at the same time being one of the essential parts of mathematics which has to be grasped if one wishes to learn and understand science and mathematics beyond the most fundamental level. It is generally agreed upon that problem-solving skills and processes are the pre-requisites for excellence in science and technology. Therefore, in the mathematics curriculum, it is of utmost importance to provide students with essential numerical capabilities in the five strands that the curriculum promotes: numbers, algebra, measurement, geometry and statistics. These strands are believed to be essential and needed not only for the students' personal lives and future work needs but for pursuing mathematics and science courses at more advanced levels which may require a strong foundation of mathematics. The mathematics curriculum also provides students with opportunities to be engaged in creative works, and in appreciating the aesthetic nature and the beauty of mathematics (Curriculum Development Department-CDD, 2011).

\subsection{Problem-Solving Skills among Secondary School Students outside Brunei}

Stevenson and Stigler (1992) have contrasted pedagogical practices between the typical United States (US) teacher and Asian countries teachers such as Japan and China. They found that teachers from the Asian countries were much readier to pose challenging questions to students and provide them opportunities to reason through the problems. The key to this comparison is that some of the misconceptions that US students have about a rote instructional approach to instruction which involves drill and kill exercises (Stevenson \& Stigler, 1992).

Mathematics problem-solving is an area of concern around mathematics achievements of US students. Darling-Hammond (2010) has found that US students fell furthest behind the PISA tasks that required complex problem-solving. Differences in approaches to the mathematics instructions steadily point to the observation that countries who significantly outperform the US on mathematics achievement have classrooms characterized by a focus on mathematical problem-solving with students interacting with real-world problems (Stevenson \& Stigler, 1992; Darling-Hammond, 2010).

The Third International Mathematics and Science Study (TIMSS) have highlighted on the 
pedagogical differences between participating countries. In a study by Stigler and Hiebert (1999), they focused specifically on such differences between the $8^{\text {th }}$-grade mathematics teachers in Japan, Germany and the United States. They have developed three different slogans to describe the norm of pedagogical approaches in each country. For Japan, the slogan for their general approach to mathematics teaching was 'structured problem-solving' characterized by posing demanding problems with students taking an active role in inventing their own solution strategies (Stigler \& Hiebert, 1999, p.27). German's mathematics instruction slogan was 'developing advanced procedures' characterized by advanced procedural problems and technical precision with applying these procedures (Stigler \& Hiebert, 1999, p.27). While for the United States, the slogan for their mathematics instruction was classified as 'learning terms and practicing procedures' characterized by less advanced problems with less demands for mathematical reasoning (Stigler \& Hiebert, 1999, p.27). Looking from these slogans, suggests some possible factors for the poor positions in international mathematics performance comparisons between the US students with the other nationalities.

\subsection{Previous Research on Teaching Mathematics to Year 7 Students in Brunei Brunei}

Previous research on teaching secondary school subjects in Brunei had focused on helping disabled students with high support needs (Bradshaw \& Mundia, 2005, 2006; Tait \& Mundia, 2012a, 2012b; Haq \& Mundia, 2012; Mundia, 2006; Tait \& Mundia, 2014; Tait, Mundia, \& Fung, 2014; Tait, Mundia, Fung, \& Wong, 2014). Apart from disability, previous research also examined the mental health concerns of students in the education system (Mundia 2010a, 2010b, 2012a, 2012b, 2013, 2015). The majority of the teaching and learning research on Brunei has investigated a wide range of school subjects including mathematics and Japanese language (Mundia, 1998, 2007, 2009, 2010c, 2010d, 2011a, 2012c; Keaney \& Mundia, 2014; Mundia \& Metussin, 2019). The training of teachers was also accorded priority by research (e.g., Mundia, 2012d, 2012e; Tait \& Mundia, 2012b, 2014). Problems associated with conducting research using Brunei student samples were investigated by two studies (Mundia \& Bakar, 2010; Mundia, 2011b). Issues related to common methods bias in research using Brunei samples were reported in two studies (Mundia, 2019a, 2019b). The scarcity of and need for research on crimes in Brunei provided the rationale and justification to conduct the current study. The inadequate research on teaching mathematics is one of reasons that prompted to conduct the present study.

\subsection{Objectives of the Study}

The main purpose and goal of the present study was to investigate the six research questions (RQs) listed below. A study with similar aims as the current investigation has not been done before in Brunei and we hope this inquiry will address the existing literature and knowledge gaps on this matter.

\subsection{Research Questions}

RQ1: Do male and female teachers have similar feelings and attitudes to the use of the BMM strategy when teaching mathematics to Year 7 students? 


\section{Macrothink}

RQ2: Do teachers of different age (age-groups) who teach Year 7 mathematics significantly differ significantly in feelings and attitudes towards the use of the BMM strategy?

RQ3: Is there any significant difference in feelings and attitudes towards the BMM strategy between teachers of Year 7 mathematics in the three different districts Brunei?

RQ4: What variables are significantly related to teaching Year 7 mathematics using the BMM strategy?

RQ5: Do the teachers' frequency of using the BMM strategy during teaching differ significantly based on their gender?

RQ6: Are the teachers' potential future use of the BMM strategy in teaching Year 7 mathematics likely to differ significantly according to their gender?

\section{Method}

The methodology for the current study included the five components (design, participants, instruments, data analysis techniques, and procedures) briefly and separately explained below.

\subsection{Design}

The study design is labelled as a case study because only few teachers $(n=127)$ out of many in the country were involved in the research. In view of this, the findings from the study were only generalized to the participating teachers.

\subsection{Sample}

Participants in this study consisted of 127 Year 7 mathematics teachers of both genders who were chosen randomly by the simple random selection procedure. The total national number of Year 7 mathematics teachers was not known at the time of collecting the data. The characteristics of the participants are presented in Table 1. 
Table 1. Characteristics of the Year 7 teachers $(\mathrm{N}=127)$

\begin{tabular}{|l|l|l|l|}
\hline Variable & Group & Frequency & Percentage \\
\hline \multirow{4}{*}{ Gender } & Male & 24 & 18.9 \\
\cline { 2 - 4 } & Female & 103 & 81.1 \\
\hline \multirow{5}{*}{ Age-group } & Below 30 & 22 & 17.3 \\
\cline { 2 - 4 } & $31-35$ & 49 & 38.6 \\
\cline { 2 - 4 } & $36-40$ & 33 & 26.0 \\
\cline { 2 - 4 } & $41-45$ & 11 & 8.7 \\
\hline & $46-50$ & 4 & 3.1 \\
\cline { 2 - 4 } & Above 50 & 8 & 6.3 \\
\hline \multirow{5}{*}{ Districts } & Brunei-Muara & 94 & 74.0 \\
\cline { 2 - 4 } & Kuala Belait & 15 & 11.8 \\
\cline { 2 - 4 } & Tutong & 18 & 14.2 \\
\hline
\end{tabular}

\subsection{Instruments}

The study used five objective Likert-type quantitative questionnaires constructed by the investigators. These included: (1) Feelings towards the BMM; (2) Frequency of use of the BMM; (3) Positive attitudes toward the BMM; (4) Negative attitudes toward the BMM; and (5) Future likelihood of using the BMM. All negative items were reversed when scoring. Descriptive statistics and reliability of the instruments are presented in Table 2.

Table 2. Descriptive statistics and alpha reliability of the questionnaires $(\mathrm{N}=127)$

\begin{tabular}{|l|l|l|l|l|l|}
\hline Scales & Items & Mean & SE Mean & SD & Alpha Reliability \\
\hline Feelings & 8 & 24.07 & 0.337 & 3.799 & 0.940 \\
\hline Frequency of Use & 4 & 7.85 & 0.234 & 2.640 & 0.886 \\
\hline Positive Attitudes & 8 & 22.17 & 0.247 & 2.769 & 0.783 \\
\hline Negative Attitudes & 3 & 7.91 & 0.138 & 1.544 & 0.721 \\
\hline Future Likelihood & 4 & 11.54 & 0.177 & 1.991 & 0.880 \\
\hline
\end{tabular}

Table 3 shows both the convergence and discriminant validity indices of the instruments. Convergence validity is demonstrated by high positive correlations while negative correlations denote evidence of discrimination validity. 
Table 3. Convergence and discriminant validity by inter-scale correlations $(\mathrm{N}=127)$

\begin{tabular}{|l|l|l|l|l|}
\hline Scales & Feelings & Frequency of use & Positive attitudes & Negative attitudes \\
\hline Feelings & 1 & & & \\
\hline Frequency of Use & $0.606^{* *}$ & 1 & & \\
\hline Positive Attitudes & $0.673^{* *}$ & $0.563^{* *}$ & 1 & \\
\hline Negative Attitudes & $-0.230^{* *}$ & $-0.289^{* *}$ & -0.123 & 1 \\
\hline Future Likelihood & $0.559^{* *}$ & $0.514^{* *}$ & $0.543^{* *}$ & -0.131 \\
\hline
\end{tabular}

Note. ${ }^{*} \mathrm{p}<.01$ (two-tailed).

\subsection{Procedures}

The present study was funded by the Government of Brunei Darussalam in form of a grant to the first author to study for doctoral degree in mathematics education in the Sultan Hassanal Bolkiah Institute of Education (SHBIE) at the University of Brunei Darussalam (UBD), a state tertiary institution. In turn, the University of Brunei Darussalam Ethics Committee approved the study on behalf of the government. Furthermore, ethical conditions and rights (e.g., anonymity, confidentiality, privacy, voluntary participation, protection from harm, and informed consent) for participating in the study were first explained verbally in both English and Bahasa Melayu language (national language) to individual research participants prior to collecting the data. After this, verbal and written informed consent were secured from each research participant in either of the two languages at the time and place of collecting the data. Only persons who voluntarily agreed to participate in the study were recruited. Coercion and deception were not used when recruiting the participants. Furthermore, all the study's research tools were written in simple English language requiring only Grade 7 or Year 7 level of education. To address and reduce any possible linguistic and cultural biases, parallel bilingual items were presented on the instruments in both English and Bahasa Melayu, the main and official language of Brunei spoken by the majority of the people. Above all, data collection occurred in in the participants' work environments to increase the study's ecological validity.

\subsection{Data Analysis}

Data were analyzed using descriptive statistics (frequencies, percentages, mean, and standard deviation) and inferential statistics (Pearson correlations, t-tests for independent groups, One-Way ANOVA and hierarchical multiple regression analysis). To determine the importance of our findings, we used two-tailed tests of statistical significance at both $\mathrm{p}=0.05$ and $p=0.01$ levels and tests of statistical power such as effect sizes (for t-tests and One-Way ANOVA analyses) and $\mathrm{R}^{2}$ (for multiple regression analyses). All the statistical analyses were performed on the Statistical Package for the Social Sciences (SPSS) Version 22. 


\section{Results}

The results are presented below according to the research questions investigated. Findings are summarized in tables.

RQ1: Do Year 7 male and female teachers have similar feelings and attitudes to the use of the BMM strategy when teaching mathematics to students?

Only one significant difference was obtained as indicated in Table 4. Male teachers had significantly higher negative attitudes toward the BMM strategy than their female counterparts $[\mathrm{t}(\mathrm{df}=125)=2.159, \mathrm{p}<.05, \mathrm{y}=0.190]$.

Table 4. Teachers' feelings and attitudes towards the BMM strategy by gender $(\mathrm{N}=127)$

\begin{tabular}{|c|c|c|c|c|c|c|c|c|}
\hline \multirow{2}{*}{ Scales } & \multicolumn{2}{|c|}{ Males $(n=24)$} & \multicolumn{2}{|c|}{ Females $(\mathrm{n}=103)$} & \multirow{2}{*}{ ANCOVA F } & \multirow{2}{*}{$\begin{array}{l}\mathrm{T} \\
(\mathrm{df}=125)\end{array}$} & \multirow{2}{*}{$\begin{array}{l}\mathrm{P} \\
\text { (two-tailed) }\end{array}$} & \multirow{2}{*}{$y$} \\
\hline & Mean & SD & Mean & SD & & & & \\
\hline Feelings & 23.50 & 3.297 & 24.20 & 3.909 & 0.473 & -0.816 & 0.416 & 0.073 \\
\hline Positive Attitudes & 21.46 & 2.797 & 22.30 & 2.768 & 0.344 & -1.340 & 0.183 & 0.119 \\
\hline Negative Attitudes & 8.50 & 1.180 & 7.75 & 1.607 & 1.764 & 2.159 & $0.033^{*}$ & 0.190 \\
\hline
\end{tabular}

Note. ${ }^{*} \mathrm{p}<.05$ (two-tailed).

RQ2: Do Year 7 mathematics teachers of different age (age-groups) differ significantly in feelings and attitudes towards the use of the BMM strategy?

According to the evidence in Table 5, no statistically significant differences were obtained by age.

Table 5. Teachers' feelings and attitudes towards BMM strategy by age-groups $(\mathrm{N}=127)$

\begin{tabular}{|l|l|l|l|l|l|l|l|l|l|}
\hline \multirow{2}{*}{ Scales } & $\begin{array}{l}\text { Below 30 } \\
(\mathrm{n}=22)\end{array}$ & $\begin{array}{l}31-35 \\
(\mathrm{n}=49)\end{array}$ & $\begin{array}{l}36-40 \\
(\mathrm{n}=33)\end{array}$ & $\begin{array}{l}41-45 \\
(\mathrm{n}=11)\end{array}$ & $\begin{array}{l}46-50 \\
(\mathrm{n}=4)\end{array}$ & $\begin{array}{l}\text { Above 50 } \\
(\mathrm{n}=8)\end{array}$ & $\begin{array}{l}\mathrm{F} \\
(\mathrm{df}=5,26)\end{array}$ & $\begin{array}{l}\text { M } \\
\text { (two-tailed) }\end{array}$ & $\mathrm{y}$ \\
\cline { 2 - 9 } Feelings & $\begin{array}{l}24.05 \\
(3.471)\end{array}$ & $\begin{array}{l}23.71 \\
(3.536)\end{array}$ & $\begin{array}{l}24.45 \\
(4.590)\end{array}$ & $\begin{array}{l}23.36 \\
(2.248)\end{array}$ & $\begin{array}{l}28.00 \\
(4.619)\end{array}$ & $\begin{array}{l}23.75 \\
(3.732)\end{array}$ & 1.102 & 0.363 & 0.209 \\
\hline \multirow{2}{*}{ Positive Attitudes } & $\begin{array}{l}22.55 \\
(2.017)\end{array}$ & $\begin{array}{l}21.86 \\
(2.821)\end{array}$ & $\begin{array}{l}22.36 \\
(3.229)\end{array}$ & $\begin{array}{l}21.18 \\
(2.228)\end{array}$ & $\begin{array}{l}25.50 \\
(3.109)\end{array}$ & $\begin{array}{l}21.50 \\
(2.000)\end{array}$ & 1.805 & 0.117 & 0.263 \\
\hline \multirow{2}{*}{ Negative Attitudes } & $\begin{array}{l}7.82 \\
(1.842)\end{array}$ & $\begin{array}{l}7.90 \\
(1.403)\end{array}$ & $\begin{array}{l}7.91 \\
(1.739)\end{array}$ & $\begin{array}{l}7.82 \\
(1.328)\end{array}$ & $\begin{array}{l}7.00 \\
(0.816)\end{array}$ & $\begin{array}{l}8.50 \\
(1.604)\end{array}$ & 0.510 & 0.768 & 0.144 \\
\hline
\end{tabular}

RQ3: Do Year 7 mathematics teachers in three selected districts of Brunei differ significantly 
in feelings and attitudes towards the BMM strategy?

No statistically significant differences were detected as shown in Table 6 below.

Table 6. Teachers' Feelings and attitudes towards BMM strategy by districts $(\mathrm{N}=127)$

\begin{tabular}{|l|l|l|l|l|l|l|}
\hline \multirow{2}{*}{ Scales } & $\begin{array}{l}\text { Brunei-Muara } \\
(\mathrm{n}=22)\end{array}$ & $\begin{array}{l}\text { Kuala Belait } \\
(\mathrm{n}=33)\end{array}$ & $\begin{array}{l}\text { Tutong } \\
(\mathrm{n}=11)\end{array}$ & $\begin{array}{l}\mathrm{F} \\
(\mathrm{df}=2,126)\end{array}$ & $\begin{array}{l}\text { P } \\
\text { (two-tailed) }\end{array}$ & $\mathrm{y}$ \\
\cline { 2 - 7 } & \multicolumn{3}{|c|}{ Mean (SD) } \\
\hline Feelings & $23.80(4.026)$ & $25.67(3.416)$ & $24.17(2.455)$ & 1.587 & 0.209 & 0.158 \\
\hline Positive Attitudes & $22.07(2.852)$ & $23.07(2.052)$ & $21.72(2.906)$ & 1.062 & 0.349 & 0.130 \\
\hline Negative Attitudes & $7.87(1.595)$ & $7.73(1.668)$ & $8.11(1.323)$ & 0.260 & 0.772 & 0.065 \\
\hline
\end{tabular}

RQ4: What variables were significantly related to effective teaching of Year 7 mathematics using the BMM strategy in Brunei?

Hierarchical multiple hierarchical regression analysis with backward elimination was used to address this research question. Teachers' gender, age, district, experience with the BMM strategy, and positive opinions of the BMM strategy (IVs) were regressed on teachers' feelings about the BMM (DV). The first required results of the analyses are presented in Table 7 below. The R-squared value for this block (0.972) indicates the common variance of $97.2 \%$ between the independent variables initially entered in model 1 (district, gender, age, attending CPD on the BMM, experience in-using the BMM, and having favorable opinions on the BMM) and the dependent variable (teachers' feelings on the BMM).

Table 7. Teachers' feelings towards the BMM strategy by hierarchical regression analysis $(\mathrm{N}$ $=127)$

\begin{tabular}{|l|l|l|l|l|l|l|l|l|l|l|l|}
\hline \multirow{2}{*}{ Model } & \multirow{2}{*}{} & \multirow{2}{*}{$\mathrm{F}$} & \multirow{2}{*}{$\mathrm{R}$} & \multirow{2}{*}{$\mathrm{R}^{2}$} & \multirow{2}{*}{ Adj $\mathrm{R}^{2}$} & $\mathrm{SE}$ & \multicolumn{5}{|c|}{ Change Statistics } \\
\cline { 7 - 12 } & & & & & & & $\Delta \mathrm{R}^{2}$ & $\Delta \mathrm{F}$ & $d f 1$ & $d f 2$ & Sig. $\mathrm{F}$ \\
\hline 1 & 6,121 & $663.851^{* * *}$ & 0.986 & 0.972 & 0.970 & 4.209 & 0.972 & 663.851 & 6 & 115 & $0.000 * * *$ \\
\hline 2 & 5,121 & $785.447 * * *$ & 0.986 & 0.971 & 0.970 & 4.237 & -0.001 & 2.574 & 1 & 115 & 0.111 \\
\hline
\end{tabular}

Note. ${ }^{* * *} \mathrm{p}<.001$ (two-tailed).

Table 8 shows that the only variable that was not significantly related to effective teaching of mathematics using the BMM was mere attendance of a CPD workshop on the BMM (see Model 1 in Table 8). After removing and adjusting for this variable, the remaining independent variables were all significant predictors of teachers' positive feelings towards the BMM (see Model 2 in Table 8). 


\section{Macrothink}

Journal of Educational Issues

ISSN 2377-2263

2020, Vol. 6, No. 1

Table 8. Hierarchical Multiple Regression with backward elimination on teachers' feelings towards the BMM $(\mathrm{N}=127)$

\begin{tabular}{|c|c|c|c|c|c|c|}
\hline \multirow[t]{2}{*}{ Model } & \multirow[t]{2}{*}{ Variables } & \multicolumn{2}{|c|}{$\begin{array}{l}\text { Unstandardized } \\
\text { Coefficients }\end{array}$} & \multirow{2}{*}{$\begin{array}{l}\begin{array}{l}\text { Standardized } \\
\text { Coefficients }\end{array} \\
\text { Beta }\end{array}$} & \multirow[t]{2}{*}{$\mathrm{t}$} & \multirow[t]{2}{*}{ Sig. } \\
\hline & & B & Std. Error & & & \\
\hline \multirow{6}{*}{1} & District & 1.330 & 0.505 & 0.086 & 2.631 & $0.010 * *$ \\
\hline & Gender & 3.582 & 0.870 & 0.271 & 4.117 & $0.000 * * *$ \\
\hline & Age & 0.875 & 0.276 & 0.105 & 3.173 & $0.002 * *$ \\
\hline & Attending CPD on BMM & 1.810 & 1.128 & 0.069 & 1.604 & 0.111 \\
\hline & Experience in using the BMM & 3.253 & 1.140 & 0.121 & 2.854 & $0.005 * *$ \\
\hline & Positive opinions on BMM & 3.220 & 0.660 & 0.374 & 4.881 & $0.000 * * *$ \\
\hline \multirow{5}{*}{2} & District & 1.324 & 0.509 & 0.085 & 2.601 & $0.011^{*}$ \\
\hline & Gender & 3.684 & 0.874 & 0.279 & 4.217 & $0.000 * * *$ \\
\hline & Age & 0.931 & 0.276 & 0.112 & 3.378 & $0.001 * *$ \\
\hline & Experience in using the BMM & 3.646 & 1.121 & 0.136 & 3.254 & $0.001 * *$ \\
\hline & Positive opinions on BMM & 3.538 & 0.633 & 0.411 & 5.585 & $0.000 * * *$ \\
\hline
\end{tabular}

Note. ${ }^{*} \mathrm{p}<0.05$ (two-tailed); ${ }^{* *} \mathrm{p}<0.01$ (two-tailed); $* * * \mathrm{p}<0.001$ (two-tailed).

RQ5: Does the teachers' frequency of using the BMM strategy during teaching differ significantly based on their gender?

For the fifth research question, the analysis involved doing cross-tabulations. Because many cells had small frequency values $(n<5)$, the chi-square and phi coefficients were not computed. Instead, only frequency values were used. It can be observed from Table 9 that the BMM was not much used by teachers on all the four items. Only a small number or percentage of teachers used the BMM strategy when instructing students in mathematics most likely due to lack of skills and experience in using the BMM 
Table 9. Teachers' frequency of using the BMM strategy by gender $(\mathrm{N}=127)$

\begin{tabular}{|l|l|l|l|l|}
\hline Statements & Never F (M) $†$ & Seldom F (M) & Often F (M) & Always F (M) \\
\hline $\begin{array}{l}\text { How often did you use the Bar Model Method in } \\
\text { your teaching this week? }\end{array}$ & $45(6)$ & $43(16)$ & $11(2)$ & $4(0)$ \\
\hline $\begin{array}{l}\text { How often did you use the Bar Model Method in } \\
\text { your teaching in the last six months? }\end{array}$ & $22(6)$ & $55(12)$ & $23(6)$ & $3(0)$ \\
\hline $\begin{array}{l}\text { How often did you use the Bar Model Method in } \\
\text { your teaching last year? }\end{array}$ & $16(3)$ & $56(13)$ & $25(8)$ & $6(0)$ \\
\hline $\begin{array}{l}\text { How often did you use the Bar Model Method in } \\
\text { your teaching this year? }\end{array}$ & $43(7)$ & $39(14)$ & $17(3)$ & $4(0)$ \\
\hline
\end{tabular}

Note. $\uparrow \mathrm{F}=$ Female; $\mathrm{M}=$ Male.

RQ6: Is the teachers' potential future use of the BMM strategy in teaching Year 7 mathematics likely to differ significantly according to their gender?

In addressing the sixth research question, tabulation and frequencies were used again. Due to the presence of cells with small frequency values less than 5, the chi-square and phi coefficients were not computed. The trend or pattern of frequencies in Table 10 suggest that more teachers of both genders were likely to use the BMM strategy in future on all four items.

Table 10. Teachers' Likelihood of future use of BMM strategy in their teaching by Gender ( $\mathrm{N}$ $=127)$

\begin{tabular}{|l|l|l|l|l|}
\hline Statements & $\begin{array}{l}\text { Very Unlikely } \\
\text { F (M) } \dagger\end{array}$ & $\begin{array}{l}\text { Unlikely } \\
\text { F (M) }\end{array}$ & $\begin{array}{l}\text { Likely } \\
\text { F (M) }\end{array}$ & $\begin{array}{l}\text { Very Likely } \\
\text { F (M) }\end{array}$ \\
\hline I am likely to use the Bar Model Method for teaching in my lessons. & $1(1)$ & $14(5)$ & $74(17)$ & $14(1)$ \\
\hline I will use the Bar Model Method in presenting my lessons. & $2(2)$ & $17(5)$ & $73(17)$ & $11(0)$ \\
\hline I will instruct students to use the Bar Model Method for their learning. & $3(1)$ & $19(7)$ & $72(15)$ & $9(1)$ \\
\hline I will use the Bar Model Method strategy in my lessons. & $2(1)$ & $10(2)$ & $80(21)$ & $11(0)$ \\
\hline
\end{tabular}

Note. $\dagger \mathrm{F}=$ Females; $\mathrm{M}=$ Males.

\section{Discussion}

Male teachers had significantly higher negative attitudes toward the BMM strategy than their female counterparts. This finding is consistent with the results of previous research which indicated that males performed poorer than females in mathematics in Brunei (Metussin, 2015). Consequently, it was quite possible that even male teachers were also less likely to 
enjoy teaching mathematics compared to female counterparts.

The only predictor variable that was not significantly related to effective teaching of mathematics using the BMM was mere attendance of a CPD workshop on the BMM. This is another finding of the current study which is well supported by previous research. The strategy is useful to teachers and students as it helps them to visualize the mathematical problem by drawing pictorial representations of the data to be analyzed (J. N. C. Huat \& L. K. Huat, 2001; Veloo \& Lopez, 1994). In Singapore, teachers use this method in primary school children who require concrete materials and approaches to solve arithmetic and algebraic word problems (Kho, 1987, 2009; Ng \& Lee, 2009).

Evidence from the present study showed that the BMM was not much used by many teachers in schools. Only a small number or percentage of teachers used the BMM strategy when instructing students in mathematics most likely due to lack of skills and experience in using the BMM. This might be due to teachers' of lack of training and experience in using the BMM method. The constructivist theory is based on the principle of encouraging students to construct, develop and challenge new knowledge by actively taking part in the teaching and learning process through social interaction (Glasersfeld, 1989). The training of teachers to equip them with new knowledge and skills was now accorded priority in the Brunei teacher education system.

Both genders were likely to use the BMM strategy in future, an indication of the degree to which they like the BMM due to its popularity. According to Walker (2005) the use of the BMM strategy was popular because it had proved to be a very successful method for students in organizing information.

\section{Conclusion}

The study found that the BMM was an effective way of teaching mathematics to students who were still in the concrete stage of reasoning. This strategy enabled students to organize information in pictorial or visual representations to help the students to understand the mathematics data and find ways of solving the mathematics problems embedded in words. Based on its usefulness, the study recommended that the BMM be taught to all teachers both preservice and in-service in Brunei. Teachers should be encouraged to use the BMM as an instructional tool.

\section{Limitations}

The present study had one main limitation. It did not include an interview component with probes to explore the participants' responses from the quantitative surveys. Further research is required to address this concern.

\section{References}

Bottge, B. A., \& Hasselbring, T. S. (1993). A comparison of two approaches for teaching complex, authentic mathematics problems to adolescents in remedial math classes. Exceptional Children, 59(6), 556-566. https://doi.org/10.1177/001440299305900608 
Bradshaw, L., \& Mundia, L. (2005). Understanding preservice teachers' construct of disability: A metacognitive process. Disability and Society, 20(5), 563-574. https://doi.org/10.1080/ 09687590500156329

Bradshaw, L., \& Mundia, L. (2006). Attitudes to and concerns about inclusive education: Bruneian inservice and preservice teachers. International Journal of Special Education, 21(1), $35-41$.

Cassel, J., \& Reid, R. (1996). Use of a self-regulated strategy intervention to improve word problem-solving skills of students with mild disabilities. Journal of Behavioral Education, 6, 153-172. https://doi.org/10.1007/BF02110230

Cawley, J. F., \& Miller, J. H. (1986). Selected views on metacognition, arithmetic problem solving, and learning disabilities. Learning Disabilities Focus, 2(1), 36-48.

Cawley, J., Fitzmaurice-Hayes, A., \& Shaw, R. (1988). Mathematics for the mildly handicapped-A guide to curriculum and instruction. Boston: Allyn \& Bacon.

CDD (Curriculum Development Department). (2011). Mathematics Year 7 and Year 8 Framework and guidelines for curriculum and assessment. Bandar Seri Begawan: Ministry of Education.

Darling-Hammond, L. (2010). The flat world and education: How America's commitment to equity will determine our future. New York, NY: Teachers College Press.

Glasersfeld, E. V. (1989). Cognition, Construction of Knowledge and Teaching. Synthesis, 80(1), 121-140. https://doi.org/10.1007/BF00869951

Haq, F. S., \& Mundia, L. (2012). Comparison of Brunei pre-service student teachers' attitudes to inclusive education and specific disabilities: Implications for teacher education. Journal of Educational Research, 105(5), 366-374. https://doi.org/10.1080/00220671.2011.627399

Hargreaves, A. (2003). Teaching in the knowledge society: Education in the age of insecurity. New York, NY: Teachers College Press.

Huat, J. N. C., \& Huat, L. K. (2001). Teacher works: Mathematics teachers in primary schools. Singapore: Singapore Times Media Private Limited.

Jitendra A. K., \& Xin Y. P. (1997). Mathematical word problem-solving instruction for students with mild disabilities and students at risk for math failure: A research synthesis. The Journal of Special Education, 30, 412-438. https://doi.org/10.1177/002246699703000404

Jitendra, A. K., \& Hoff, K. (1996). The effects of schema-based instruction on the mathematical word-problem-solving performance of students with learning disabilities. Journal of Learning Disabilities, 29, 422-431. https://doi.org/10.1177/ 002221949602900410

Jonassen, D. H. (2003). Designing research-based instruction for story problems. Educational Psychology Review, 15(3), 267-296. https://doi.org/10.1023/A:1024648217919

Keaney, M., \& Mundia, L. (2014). Foreign language learners' motivation and its effects on 
their achievement: Implications for effective teaching of students studying Japanese at Universiti Brunei Darussalam. International Education Studies, 7(9), 122. https://doi.org/ 10.5539/ies.v7n9p122

Kho, T. H. (1987). Mathematical models for solving arithmetic problems. Proceedings of the Fourth Southeast Asian Conference on Mathematical Education (ICMI-SEAMS), Mathematical Education in the 1990's (pp. 345-351). Singapore: Institute of Education.

Kho, T. H., Yeo, S. M., \& Lim, J. (2009). The Singapore Model Method for Learning Mathematics. Singapore: EPB Pan Pacific.

Mayer, R. E. (1992). Thinking, problem solving, cognition. New York, NY: WH Freeman/Times Books/Henry Holt \& Co.

Metussin, H. (2015). Where are the males? Potential causal factors of the gender gap in higher education in Brunei and implications for educators. A thesis in partial fulfilment of the requirements for the Degree of Doctor of Philosophy. Bandar Seri Begawan: Sultan Hassanal Bolkiah Institute of Education, University of Brunei Darussalam.

Miller, S. P., \& Mercer, C. D. (1993). Mnemonics: Enhancing the math performance of students with learning difficulties. Intervention in School and Clinic, 29, 78-82. https://doi.org/10.1177/105345129302900204

Montague, M. (1992). The effects of cognitive and metacognitive strategy instruction on the mathematical problem solving of middle school students with learning disabilities. Journal of Learning Disabilities, 25, 230-248. https://doi.org/10.1177/ 002221949202500404

Moore, L. J., \& Carnine, D. (1989). Evaluating curriculum design in the context of active teaching. Remedial and Special Education, 10, 28-37. https://doi.org/10.1177/07419325890 1000406

Mundia, L. (2006). Aggressive behavior among Swazi upper primary and junior secondary school students: implications for ongoing educational reforms concerning inclusive education. International Journal of Special Education, 21(3), 58-67.

Mundia, L. (2007). Early childhood education in Swaziland and Brunei Darussalam: Goals, achievements and challenges. Early Child Development and Care, 177(2), 151-158. https://doi.org/10.1080/03004430500375885

Mundia, L. (2009). Implementation of inclusive education in Brunei Darussalam: Review of possible implications on school counsellors. Electronic Journal for Inclusive Education, 2(4). Retrieved from http://www.cehs.wright.edu/ prenick/Spring_Summer09_Edition/spr_sum 09.html

Mundia, L. (2010a). Prevalence of depression, anxiety and stress in Brunei student teachers. Internet Journal of Mental Health, 6(2). https://doi.org/10.5580/18c7

Mundia, L. (2010b). Brunei trainee teachers' coping strategies for stressful situations. International Journal of Psychological Studies, 2(1), 79-88. https://doi.org/10.5539/ijps. 
$\mathrm{v} 2 \mathrm{n} 1 \mathrm{p} 79$

Mundia, L. (2010c). Problems in learning mathematics: Comparison of Brunei junior high school students in classes with and without repeaters. Journal of Mathematics Research, 2(3), 150-160. https://doi.org/10.5539/jmr.v2n3p150

Mundia, L. (2010d). Implementation of SPN21 curriculum in Brunei Darussalam: A review of selected implications on school assessment reforms. International Education Studies, 3(2), 119-129. https://doi.org/10.5539/ies.v3n2p119

Mundia, L. (2011a). Effects of psychological distress on academic achievement in Brunei student teachers: Identification challenges and counseling implications. Higher Education Studies, 1(1), 51-63. https://doi.org/10.5539/hes.v1n1p51

Mundia, L. (2011b). Social desirability, non-response bias and reliability in a long self-report measure: Illustrations from the MMPI-2 administered to Brunei student teachers. Educational Psychology: An International Journal of Experimental Educational Psychology, 31(2), 207-224. https://doi.org/10.1080/01443410.2010.545049

Mundia, L. (2012a). The mental health profiles of student teachers: Relevance to teacher education and in identifying potential future teacher problems. The Internet Journal of World Health and Societal Politics, 7(2). https://doi.org/10.5580/2c75

Mundia, L. (2012b). The role of cognitive behavior therapy in fighting non-adherence to medical advice maintained by fear of drug side-effects in a man with cholesterol, obesity and hypertension problems. The Internet Journal of Health, 13(1). https://doi.org/10.5580/2c41

Mundia, L. (2012c). The Assessment of Mathematics Learning Difficulties in a Primary Grade 4 Child with High Support Needs: Mixed Methods Approach. International Electronic Journal of Elementary Education, 4(2), 347-366.

Mundia, L. (2012d). Assessment of GenNEXT learning outcomes at the University of Brunei Darussalam: A qualitative review of selected opportunities, benefits and challenges in human resource development. Journal of International Education and Leadership, 2(3).

Mundia, L. (2012e). Policy changes in Brunei teacher education: Implications for the selection of trainee teachers. The Education Forum, 76(3), 326-342. https://doi.org/10.1080/00131725. 2012.682489

Mundia, L. (2013). Relationship between Mental Health and Teaching: Evidence from Brunei Trainee Teachers. International Journal of Mental Health, 42(2/3), 73-98. https://doi.org/ 10.2753/IMH0020-7411420205

Mundia, L. (2015). The Relationship between Personality and Emotional Intelligence: An Exploratory Case of Brunei Student Teachers. Mediterranean Journal of Social Sciences, 6(6S1), 133. https://doi.org/10.5901/mjss.2015.v6n6s1p133

Mundia, L. (2017). How Brunei trainee teachers cope with distress: Counseling implications. BMC Research Notes, 10, 596. https://doi.org/10.1186/s13104-017-2922-0 
Mundia, L. (2019a). Satisfaction with work-related achievements in Brunei public and private sector employees. Cogent Management \& Business, 6(1). https://doi.org/10.1080/23311975. 2019.1664191

Mundia, L. (2019b). Interpersonal Trust in Brunei Public and Private Sector Employees. In A. Farazmand (Ed.), Global Encyclopedia of Public Administration, Public Policy, and Governance. https://doi.org/10.1007/978-3-319-31816-5

Mundia, L., \& Bakar, H. (2010). The suitability of the EPQ-R short scale for counseling Brunei student teachers when administered in English and Malay languages. Compare, 40(5), 641-658. https://doi.org/10.1080/03057920903478654

Mundia, L., \& Metussin, H. (2019). Exploring factors that improve mathematics achievement in Brunei. Studies in Educational Evaluation, 60, 214-222. https://doi.org/10.1016/j.stueduc. 2018.10.003

NCTM (National Council of Teachers of Mathematics). (1989). Curriculum and Evaluation Standards for School Mathematics. Prepared by working groups of the Commission on Teaching Standards for School Mathematics of the National Council of Teachers of Mathematics. Reston, VA, March.

NCTM (National Council of Teachers of Mathematics). (2000). Principles and Standards for School Mathematics. Reston, VA: National Council of Teachers of Mathematics.

Newell, A., \& Simon, H. A. (1972). Human problem solving. Englewood Cliffs, NJ: Prentice-Hall.

Ng, S. F., \& Lee, K. (2009). The Model Method: Singapore children's tool for representing and solving algebraic word problems. Journal for Research in Mathematics Education, 40(3), 282-313.

Polya, G. (1957). How to solve it: A new aspect of mathematics method. Princeton, NJ: Princeton University Press.

Radiah, M. (2001). The difficulties faced by students of Brunei Darussalam in transforming short mathematical word statements into algebraic form (Unpublished M.Ed. dissertation, Bandar Seri Begawan, University of Brunei Darussalam).

Raimah, M. (2001). An investigation of errors made by Primary 6 pupils in word problems involving fractions (Unpublished M.Ed. dissertation, Bandar Seri Begawan, University of Brunei Darussalam).

Sainah, N. (1998). Problem solving errors by primary six children in specialist teachers' project schools (Unpublished M.Ed. dissertation, Bandar Seri Begawan, University of Brunei Darussalam).

Saman, A. (2000). Investigating understanding by primary six pupils of word problems involving multiplication and division (Unpublished M.Ed. dissertation, Bandar Seri Begawan, University of Brunei Darussalam). 
Shaw, M. E. (1981). Group dynamics: The psychology of small group behavior (3rd ed.). New York, NY: McGraw-Hill.

Stevenson, H. W., \& Stigler, J. W. (1992). The learning gap: Why our schools are failing and what we can learn from Japanese and Chinese education. New York: Simon and Schuster Paperbacks.

Stigler, J. W., \& Hiebert, J. (1999). The teaching gap: Best ideas from the world's teachers for improving education in the classroom. New York, NY: The Free Press.

Tait, K., \& Mundia, L. (2012a). Preparing teachers to meet the challenges of inclusive education in Negara Brunei Darussalam. In C. I. Forlin (Ed.), Future directions for inclusive teacher education: An international perspective (pp. 60-69). Hong Kong: Routledge/Francis \& Taylor.

Tait, K., \& Mundia, L. (2012b). The impact of a child with autism on the Bruneian family system. International Journal of Special Education, 27(3), 1-14.

Tait, K., \& Mundia, L. (2014). A Comparison of Brunei and Hong Kong-SAR Student Teachers' Self-efficacy in Implementing Inclusive Education Practices: Implications for Teacher Education. Asian Social Science, 10(1), 51-60. https://doi.org/10.5539/ass.v10n1p51

Tait, K., Mundia, L., \& Fung, F. (2014). Raising Young Children with Autism Spectrum Disorders in Hong Kong: The Impact of Cultural Values and Stigma on Chinese Parents' Coping Strategies. International Journal of Advances in Social Science and Humanities, 2(1), 07-157.

Tait, K., Mundia, L., Fung, F., \& Wong, C. (2014). The impact of traditional Chinese beliefs, stigma and local school service provision on the coping strategies of parents of children with Autism Spectrum Disorders in Hong Kong. Journal of the International Society for Teacher Education, 18(1), 16-25.

Tait, K., Mundia, L., Fung, F., \& Wong, C. (2014). The impact of traditional Chinese beliefs,stigma and local school service provision on the coping strategies of parents of children with Autism Spectrum Disorders in Hong Kong. Journal of the International Society for Teacher Education, 18(1), 16-25.

Taplin, M. (2006). Mathematics through problem solving. Retrieved May 5, 2019, from http://tvslvslearningforum.org/pdf/classroom_practices.pdf

Van de Walle, J. A., Karp, K. S., \& Bay-Williams, J. M. (2004). Elementary and middle school Teaching developmentally (5th ed.). Boston, MA: Allyn \& Bacon.

Veloo, P. K., \& Lopez, R. F. (1994). Drawing diagram and solving word problems: A study of a sample of Bruneian primary and secondary school children in mathematics. Proceedings of the Seventeenth Annual Conference of the Mathematical Education Research Group of Australasia, 2, 667-674.

Walker, K. (2005). Problem solving and investigational activities in your classroom 


\section{Macrothink}

Journal of Educational Issues

ISSN 2377-2263

2020, Vol. 6, No. 1

(Unpublished report, Educational Technology: Bandar Seri Begawan: Sultan Hassanal Bolkiah Institute of Education, Universiti Brunei Darussalam).

Wallas, G. (1926). The art of thought. New York, NY: Harcourt.

Yeap, B. H. (2011). Bar Modeling: A problem-solving Tool. Singapore: Marshall Cavendish Education.

Yusuf, N. M., \& Mundia, L. (2014). The status of counseling in Brunei prisons: Qualitative exploratory case study. Journal of Sociological Research, 5(1), 24-39.

\section{Copyright Disclaimer}

Copyright for this article is retained by the author(s), with first publication rights granted to the journal.

This is an open-access article distributed under the terms and conditions of the Creative Commons Attribution license (http://creativecommons.org/licenses/by/3.0/). 